\title{
The Global AND the Local: Precautionary Behaviours in THE Realms of Crime, Health, ANd Home SAFETY
}

\author{
ERIN GibBS VAN BRUnSChOT \\ JASON LAURENDEAU \\ LESLIE-ANNE KEOWN
}

\begin{abstract}
Expressions of anxieties are examined in the realms of crime, health and home safety. We consider protective behaviours that individuals undertake in each of these realms as potential outlets for the expression of anxiety; the way in which elements of social context such as age, education and income, and biographical factors including past experiences, perceived control, and anxieties about future events contribute to protective behaviours within each realm is examined. Findings indicate different factors drive precautionary behaviours for men and women, suggesting gender as a lens through which precautionary behaviours are taken up. Global anxiety inconsistently predicts precautionary behaviours - a finding that questions both the utility of and the theoretical significance of global anxiety. Local (individual) negative experiences within these realms play an important role in predicting preventative behaviour, although the impact of negative experiences among the realms and between the sexes is inconsistent. Light is shed on the relationship between global anxieties and local expressions suggesting that behaviour may have a far more local element than might be expected.
\end{abstract}

Keywords: risk, anxiety, protection, gender, crime, health, safety

Résumé. Les manifestations d'anxiété sont examinées dans les domaines de la criminalité, de la santé et de la sécurité résidentielle. Nous considérons les prises de comportements préventifs faites par les individus, dans chacun de ces domaines comme des débouchés potentiels à une manifestation d'anxiété, de même que chaque élément de contextes sociaux, tels que : l'âge, l'éducation, le revenu ; et de facteurs biographiques incluant les expériences passées, l'impression de contrôle, et les inquiétudes sur des événements futurs, peuvent contribuer à la présence d'un comportement préventif au sein de chacun de 
ces domaines, sont examinés. Les recherches indiquent que différents facteurs motivent les conduites préventives chez l'homme et chez la femme, suggérant le sexe de chacun comme une lentille au travers de laquelle les comportements de précaution seraient absorbés. Inconséquemment, l'Anxiété générale laisse présager une prise de comportements préventifs, mais cette constatation remet en question autant l'utilité que la portée théorique de l'Anxiété générale. Dans la prédiction de comportements préventifs, les expériences individuelles d'anxiété négatives jouent un rôle important dans ces domaines, bien que l'impact de ces expériences négatives dans ces domaines ou entre les différents sexes soit contradictoire. La lumière est alors faite sur la relation qui existe entre l'anxiété au sens large et les expressions individuelles qui suggèrent qu'un comportement pourrait être porteur d'un élément bien plus personnel que ce à quoi l'on pourrait s'attendre.

Mots clés: risque, anxiété, protection, sexe, crime, santé, protection.

\section{INTRODUCTION}

Cheorists such as Beck (1992) and Giddens (1994) describe late modernity as characterized by a generalized anxiety. Beck's "risk society" thesis posits that science and technology are no longer seen as offering solutions to various problems, as was characteristic of the early modern era. Instead, doubts as to the benefits of science and technology have become increasingly pervasive. Giddens' understanding of late modernity extends Beck's notion of risk society by suggesting that late modernity is characterized by a generalized sense of anxiety and fear of the unknown. Generalized feelings of anxiety and dread are said to be increasingly pervasive, as we can no longer identify from where threats may emerge.

The question remains, however, as to what people do with this insecurity. Is insecurity manifested in particular behaviour? In the analysis that follows, we consider the behavioural expression of anxiety and the observation that global anxieties may find an outlet for individual expression in the realm of crime prevention (Hollway and Jefferson 1997). We extend this argument and suggest that anxieties may also find expression in the realms of ill-health and home safety preparedness. We consider preventive and protective behaviours that individuals undertake with respect to crime, ill-health, and home safety as outlets for the expression of anxiety, and consider how various characteristics and experiences contribute to preventive and protective behaviours within each of these realms. 


\section{Global AnXieties...}

Risk society theorizing suggests that the threats we face today are global and universal. Damage to the environment, for example, does not recognize borders, nor does it recognize class status. As Mythen and Walklate note, there has been a

movement away from differential class-consciousness toward a universal risk-consciousness. In essence, the foremost threats of the world risk society - ecological conflicts, financial crises and global terror networks - remain constant across space and place. (2006:384)

Although threats in the world risk society may be constant and equally threatening, individual actors do not necessarily register these threats in any constant or comparable way. While acid rain, for example, may indeed be a problem for all of us, the relevance of this threat varies widely depending upon one's life circumstances. Our ability to think globally depends very much upon local circumstances and situations (Taylor 1997).

A central premise of risk society theorizing is that our previously institutionally ordered society has become an individualized society. The result, as Mythen and Walklate explain, is "the proliferation of an everyday culture of risk plac[ing] burdensome demands upon the self, forcing individuals to habitually make reflexive choices" (2006:383). This "everyday culture of risk" is accompanied by a neoliberal version of individualization, meaning that individuals are increasingly asked to rationally assess their vulnerabilities to various hazards. The burden placed on individuals is one of acquiring information that may be used to identify threats, assessing vulnerability to these threats, and determining how identified threats may be dealt with and addressed. Individuals may consider the costs of avoiding exposure to threats, for example, as well as the costs of redressing damage or harm that may result as a consequence of exposure to these hazards. Given this self-assessment, in an individualized risk society there may be a tendency to prioritize and seek to address local and concrete hazards over and above addressing abstract global threats. As Haggerty (2003) notes, there may be a somewhat antisocial element to determinations of what individuals perceive as (locally) threatening.

Global threats, and hence global anxieties, are more likely to resonate with individuals if there is a local context into which these more abstract threats may be placed. The global threat of terrorism, for example, has relatively little impact on the way the majority of individuals around the globe carry out their lives, as most have little direct experience with 
this kind of threat. (At the same time, airline travelers worldwide are restricted in what they can and cannot take on board.) This type of global threat is more likely to resonate with particular individuals if they have been exposed to terrorism or its immediate consequences (or, more recently, if and when they travel on airplanes). Similarly, the global threat of SARS (Severe Acute Respiratory Syndrome) in 2003 resonated most particularly with those undertaking international travel, and those who were believed to have come into contact with these international travelers. Even for those who may be more likely to be exposed to threats, the ways in which individuals register vulnerability depends upon their experiences with similar threats and the life circumstances in which individuals find themselves; notably, economic circumstances play a large role (Smith 2006). Local circumstances filter our responses to dangers and threats - especially threats that may only exist, for many, in the (global) abstract.

\section{...AND LOCAL EXPRESSION}

The idea that there are global and local considerations in the determination of risk is paralleled to a degree in the fear of crime literature which suggests that there are both rational and subjective considerations which play a role in fear of crime (and in determinations of crime risk). Hollway and Jefferson (1997) contend that the research literature on fear of crime has been driven by a debate between (subjective) fear and (objective) risk. They argue that the literature sets up a false dualism between fear and risk, suggesting that if individuals could simply become more informed of their objective probability of victimization - their actual risk of crime - then their fear of crime would likewise be reduced. The crux of the risk/fear debate is that because individuals are rational and calculating, providing appropriate information would subsequently relieve fear. Hollway and Jefferson argue, on the other hand, that this oversimplifies fear of crime, and fails to take into account the cultural and individual contexts in which individuals live and in which "fear of crime" finds expression.

Instead, Hollway and Jefferson argue that fear of crime must be situated within the context of late modernity and the generalized anxiety characteristic of society today. This observation is supported to some extent by the work of Grey, Jackson, and Farrall (2008) who suggest that global anxiety, which is diffuse, may differ substantially from specific anxiety. Part of this more global anxiety may be due to an emphasis on order and control, as well as the perception that things happen for a reason. Douglas 
(1992), for example, maintains that we live in a "blame society" and that accountability is central - blame is often laid in an attempt to reduce uncertainty and to restore perceptions of order and control. Further, if we become victims, we expect not only others to at least partially blame us for our own plights, but we may also blame ourselves for failing to take appropriate precautionary measures. This is part of a responsibilization strategy that Garland (1996) refers to, where individuals are encouraged and convinced to accept responsibility for their well-being. Media campaigns, Garland notes, often help to "raise consciousness, create a sense of duty and thus change practices" (1996:452).

With respect to behaviour in the context of crime prevention, Haggerty (2003) suggests that the idea of individuals rationally calculating how they will respond to various crime threats is a neoliberal idealization. Instead, he suggests that crime prevention activities may be "informed by a host of other emotional, symbolic, and cultural considerations" (2003:195) and are not necessarily calculations informed by rationality alone. Haggerty observes that the ways in which we respond to crime threats, as well as other threats, involves a "precautionary logic." This means that individuals do not calculate risk, but operate on the basis of "subjective uncertainty about the probability of victimization" (2003:203).

Although rational calculation may figure only more or less in terms of defensive actions against potential crime harm, a form of calculation based on experience does appear to influence the defensive actions that individuals take in the face of disasters. Norris, Smith, and Kaniasty (1999), for example, found that victims of Hurricane Hugo differed in the extent to which they undertook defensive behaviours in the aftermath of the hurricane. Specifically, they found that proximity to the disaster was the most significant factor: those who were closest to the disaster took more precautionary behaviours in its aftermath than did those who were further from the damage. These findings suggest that there is more to protective behaviour than simply the expression of "generalized anxiety." Individual experiences, along with social context and perceived proximity to threats, are likely to come into play (Krewski et al. 2008). Protective actions therefore cannot be understood without acknowledging individual experiences, which affect the ways in which individuals perceive and approach the world.

What fear of crime discourse and crime prevention behaviour may accomplish is housing more generalized and abstract threats. The fear of crime discourse makes threats to security known; makes possible victims known ("might I be victimized, and what can I do about it?"); and may provide for the mastery or control over anxiety through particular crime (or other) prevention activity. In his consideration of anxiety, Hunt 
(1999) explains that a number of anxieties may converge before they result in action. Hunt also reminds us to pay particular attention to the level of anxiety that may or may not manifest itself in action. He suggests that if "anxiety is a general feature of the human condition it is important to consider under what conditions anxieties manifest themselves in overt social action" (1999:514). Crime prevention activities may therefore indicate a site of convergence of a number of anxieties from a number of sources, not simply anxiety having to do with crime itself. As Hollway and Jefferson (1997:265) note, fear of crime is an apt discourse, "since the risks it signifies, unlike other late modern risks, are knowable, decisionable (actionable) and potentially controllable." But mastery or control over potential criminal victimization is not the only venue through which anxieties might converge and be expressed. Protective action in the realms of health and home safety might also be considered similarly expressive, actionable, and seemingly controllable.

\section{Crime, Ill Health, and Home Safety}

The more generalized anxiety characteristic of today's society may also find opportunity for expression within the discourses associated with "fear of ill-health"/"health promotion" and "home safety." In the same way that crime prevention discourses enable the identification of potential victims of crime and their vulnerabilities, discourses of health promotion also identify those who are considered unhealthy and further identify hazards to health in the form of certain foods, drinking, or smoking, etc. (Risor 2006). Home safety discourses similarly identify vulnerable homes those which lack smoke detectors; those characterized by improperly stored chemicals and flammables; and those without insurance, to name a few. The characteristics that make one's body and home vulnerable to particular threats are identifiable - an individual can attempt to assess his or her likelihood of being robbed, becoming ill, or having his or her house catch on fire. As with the fear of crime discourse, health promotion and home safety discourses make vulnerability knowable in terms of identifying threats to body and home, and identifying ways to minimize and control these threats.

Like crime prevention, health promotion, and home safety discourses speak to "decisionability" or action - steps can be taken to avoid endangering one's health and home, and to safeguard against negative outcomes. Just as individuals attempt to protect themselves against criminal victimization by locking doors and barring windows, they can also become aware of and identify potential threats to their health - safeguarding themselves against illness by watching their diets 
and getting adequate exercise and sleep. Similarly, they may engage in practices to protect their homes from disaster by, for example, installing smoke detectors.

The same social context that fosters the crime prevention discourse appears also to give currency to the health promotion and home safety preparedness discourses. Added to social context is the importance of individual biographies - past experiences of criminal victimization, illhealth, and disaster. As with those who have been criminally victimized, the experience of previous (or ongoing) ill-health will affect the "outlet of expression" that the health promotion discourses authenticate, as will the experience of disaster influence the precautionary measures taken to protect one's home. How, for example, does the experience of disease manifest in the health promotion (or other) behaviours of those who have had such illness experiences? How does having experienced a fire influence one's home safety (or crime victimization) preparedness initiatives? As with criminal victimization and crime prevention, the experience of a serious health issue or home disaster may alter the types of preventative behaviours that find expression for certain individuals both within and outside the realms of that particular experience.

The focus of our investigation is the ways in which aspects of the social context and individual biography figure into the types of prevention activities (outlets of expression) undertaken by individuals with respect to crime prevention, health promotion, and home safety preparedness. In particular, our interest is in exploring the links between experiences and subsequent preventative behaviour within particular realms, but we are also interested in determining if (and how) experiences and perceptions within one realm may cross over to the other realms under examination: is there evidence of convergence among these realms of anxiety? Before we consider these relationships, we first consider why it is appropriate to examine separately the experiences of men and women with respect to the protective behaviours in which they may engage.

\section{GeNDER AND RisK}

As numerous researchers have observed, gender is more than simply a variable in understanding risk, victimization, and precautionary behaviour. Considering primarily criminal victimization, researchers persuasively argue that discourses around, and individual perceptions of, risk and victimization are gendered (e.g., Chan and Rigakos 2002; Madriz 1997; Walklate 1997). Therefore, the meaning of precautionary behaviours is very different for men and women (Madriz 1997). As Chan and 
Rigakos (2002:756) suggest, gender may be a lens through which risk is understood and negotiated: women view the world in different ways, identifying different potential harms than do men. Walklate (1997), for instance, points out that women and men are subject to different kinds of criminal victimization, with men more likely to be victims of crimes in public (except sexual assault), while women are more likely than men to be victims of crime at the hands of someone known to them in the "safety" of their homes.

Walklate also suggests that it is important to consider women's and men's relationships to fear and anxiety within a matrix of understanding what it means to be a woman or a man. Dominant codes of masculinity emphasize risk-taking, fearlessness, adventure, and control, and may go some way towards explaining why men routinely report more interest in voluntary risk activities and lower levels of fear with respect to victimization (Walklate 1997:41). Similarly, cultural understandings of femininity and motherhood, for instance, shape some women's understandings of their vulnerability to victimization, and the importance they attach to taking action against negative outcomes, be they criminal, health related, or rooted in natural disasters (Bord and O'Connor 1997; Culley and Angelique 2003; Fothergill 1996). Indeed, Madriz points out that the notion of "appropriate" femininity and the fear of victimization to which these ideas are tied serve as forms of social control over women. Her focus group and interview data revealed that women (especially white women) were often understood as being more vulnerable to victimization than men because they were more often depicted as victims in popular media imagery. This reinforces the "belief that women have the monopoly on submissiveness and men on aggression, that men have control of the streets, and women belong in the home," and carries with it implicit codes of behaviour to "avoid the streets, stay inside, avoid strangers, dress properly" (Madriz 1997:353-54). Taken together, these studies suggest dominant understandings of men as risk-takers and women as risk-managers (for an insightful discussion of this distinction in the realm of extreme sport, see Kay and Laberge 2004).

In the analysis that follows, we consider the impact that personal experience and social context appear to play for both men and women regarding precautionary behaviours. Though our examination highlights gender, we recognize that other characteristics such as race and class may also figure into how preventative behaviours are undertaken. We choose to highlight gender in this examination of protective behaviours due to the "imagistic discourse [which] suggests that men have bodies that will prevail, that are strong and impenetrable" (McCaughey 1997:36). Hollander's examination of the discourse of violence reiterates, for example, 
that perceptions and expectations associated with men's and women's vulnerability, "have far reaching consequences for the daily practices of women and men, in terms of the strategies they use to keep themselves safe" (2001:85). Our analysis explores whether personal experience and social context operate in similar or dissimilar ways for women and men, and weighs in on the discussion of whether risks might be best understood as gendered in the identified realms.

\section{Method}

The data used for this project are from a survey of 1200 adults residing in Alberta, Canada. The questionnaire contained a number of items, including attitudes toward and behaviours with respect to the realms of crime, health, leisure, finances, nature, and technology. Standard demographic questions were also included. A sample of telephone numbers, using random digit dialling techniques, was drawn for three areas of the province - two metropolitan areas, Calgary and Edmonton, and rural Alberta. Data were collected in the fall of 2002. The survey took approximately 45 minutes to complete - a lengthy survey which may have affected the overall response rate, at $35 \%$.

There is some debate regarding the utility of survey methods to fully capture perceptions and complicated, situationally specific interpretations. Although our study focuses on both behaviours and perceptions, the types and nature of the questions that particular methods are able to address are different. Tulloch notes that we assume "standardized closed questions" to readily reflect "shared fixed systems of meaning" (2004:364). She further observes that with survey research, "respondents frequently reply readily to closed questions, presumably on the basis of some perceived shared understandings of the research process and relevant constructs" (2004:364). We negotiate and conduct our everyday lives based upon meanings that we assume others share: these assumptions reflect general understandings of our social world. Yet even personal interviews may reflect an account that is negotiated and socially constructed. Frosh and Emerson (2005:308) observe: given that "meaning is not fixed but is constructed in specific situations and usually through particular intersubjective encounters, then alternative interpretations of any text are likely to be viable and may even be equally persuasive." Survey methods may therefore also provide an alternative "text" or interpretation of particular understandings.

Demographic variables represent, somewhat abstractly, the notion of social context. Particular demographic characteristics come to the fore at 
various points in history, making certain individuals more or less vulnerable, as well as more or less receptive to taking action to ensure protection. Because our data are individual-level, we account for social context through these less direct, individual-level variables. Although often perceived as control variables, sociodemographic variables provide some insight into how an individual may experience the social world. For example, those who are older have more life experience to draw upon than those who are younger, suggesting that world views may be impacted by respective age. The notion of "stranger danger," for example, may be a concept that the elderly have never dealt with, but which may affect those who are younger by heightening anxiety associated with public spaces. The sociodemographic characteristics that we include are education, age, income, and marital status (see Appendix One).

Personal biography includes individual experiences and perceptions that may uniquely influence protective behaviours. The first dimension of personal biography is experiential: two measures of past experiences were included for each of the realms (crime, health, and home safety) under consideration. Previous crime victimization consisted of answering the following question in the affirmative: "An attack can be anything from being hit, slapped, pushed or grabbed, to being shot or beaten. Have you ever been attacked by anyone?" We chose not to include property crime victimization due to the fact that, overall, this was a relatively common occurrence and therefore property victimization was characterized by little variability. A second experiential measure of personal biography in the crime realm included: "In the past year, has a close friend or relative of yours been the victim of a crime?" In the realm of health, respondents were asked if they had experienced (1) a major illness requiring hospitalization, or (2) a major injury for which hospitalization was required, in the past five years. Answering affirmatively to either of these questions was evidence of having experienced a health hazard. While our measures of health promotion speak more to the issue of illness than injury, a serious injury (and the associated experience of hospitalization) may sensitize respondents to issues of health. With respect to experience with hazards potentially affecting one's home, respondents were asked: (1) "Have you directly experienced a major natural disaster (flood, forest fire, tornado) or its immediate effects?"; (2) "Have you directly experienced a man-made disaster (gas leak or house fire) or its immediate effects?" Answering in the affirmative to either (or both) of these questions was considered indicative of past hazard experience.

A second dimension of personal biography consists of individual perceptions of the future, which we refer to as general anxiety and financial anxiety. The general anxiety variable was a composite measure 
of 14 variables scored on a scale of 1-10. The fourteen variables were summed and divided by 14 to retain the original 1-10 scaling. All questions used in the generalized anxiety variable were prefaced with the following: "Please rate the chance that a specific event will happen to you in the next five years. On a scale of 1 to 10 , where 1 means it is 'not at all likely' and 10 means it is 'very likely' - how likely do you think it is that...." The scale included items related to crime, health, and home safety (see Appendix One). A preliminary common factor analysis of the variables indicated three factors: crime anxiety, health anxiety, and disaster anxiety. A second order common factor analysis indicated a single second-order factor between the three previously identified factors. A factor score was created and its correlation with a score obtained by summing the 14 questions and dividing by 14 produced a correlation above .9. Thus, the summed score was used since it retained the original scoring algorithm of the questions.

A financial anxiety variable was created from a single question: "On a scale of 1 to 10 , where 1 means it's 'not at all likely' and 10 means it's 'very likely' - how likely do you think it is that you will face a major financial hardship?" This question did not load in any of the abovementioned factors, but we chose to retain this measure as a separate indicator given the significance of financial security to perceived anxiety. It is worth noting that both our general anxiety and financial anxiety measures address what might be considered more objective aspects of anxiety as we are asking whether respondents believe particular negative events are likely to occur. These measures do not as clearly address the emotive dimension - how worried respondents are about these types of occurrences. We return to this point in the discussion.

A final dimension of personal biography was personal coping style. The first measure dealt with views of control/preparedness. It consisted of two questions, again prefaced by asking respondents to indicate their level of agreement (strongly agree, agree somewhat, disagree somewhat, strongly disagree) with the following statements: "I devote much thought and effort to preparing for the future" and, "when things get complicated, I tend to try even harder." These questions were summed and divided by two. The second measure, risk engagement, consists of a single question: "Indicate your level of agreement (strongly agree, agree somewhat, disagree somewhat, strongly disagree) with the following statement: I like to test myself every now and then by doing something risky." This variable was recoded so that 1 indicated agreement and 0 indicated disagreement in order to more closely reflect the dichotomous distribution of the variable. 
Our analysis includes three dependent variables: crime protection, health promotion, and home protection. The following preceded the crime protection questions:

People sometimes make a habit of doing certain things on a regular basis to keep them safer from crime. The following questions apply to what you NORMALLY do in the course of your everyday or routine activities in the area in which you live. Do you routinely [or most of the time]...

(1) Carry something (weapon, pepper spray) to defend yourself or (whistle) to alert other people?;

(2) Lock the car doors when alone in a car?;

(3) Check the back seat for intruders when returning alone to a parked car?;

(4) Stay at home at night because you are afraid to go out alone?;

(5) Avoid certain areas because of crime?;

(6) Keep lights on when home alone?;

(7) Close your blinds or curtains when home alone?;

(8) Hold your keys defensively when walking alone at night?

These measures were coded as yes (1) or no (0) and were summed to provide an additive crime prevention score (with a minimum score of 0 and a maximum of 8 ). The health promotion score consisted of adding responses to the following questions:

In terms of your physical health, do you...

(1) Avoid fat in your diet?

(2) Avoid cholesterol in your diet?

(3) Avoid salt in your diet?

(4) Avoid loud noise?

(5) Eat fruits and vegetables?

(6) Take vitamins?

(7) Regularly smoke? [reverse-coded].

Scores on the individual items were added, resulting in a measure ranging from 0 to 7 . Finally, home safety preparedness consisted of the following six items:

Please consider the following questions as they relate to your home environment. Do you...

(1) Own a working battery-powered radio at home?

(2) Have working smoke alarms/detectors at home?

(3) Have a first aid kit at home?

(4) Have a working fire extinguisher at home? And

(5) Have a plan to follow in case of a house fire? 
These questions were added together, creating a score with a minimum value of 0 and a maximum value of 5. Appendix One describes all measures. Table 1 provides a summary of each measure.

Overall, we see that our sample has an average age of approximately 44 years, and is relatively well educated (averaging nearly 14 years). As a sample, they express some anxiety, both in terms of the generalized anxiety measure described earlier and slightly more so with respect to finances. On average, respondents engage in approximately three of the eight crime prevention behaviours, just over four of the seven health promotion behaviours, and roughly 3.5 of the five home safety preparedness behaviours. Nearly $35 \%$ have been victims of personal crime, while almost $28 \%$ have a close relationship to someone who has been a crime victim. About one in five have experienced a serious illness, and over

\section{Table 1: Variable Description}

\begin{tabular}{|c|c|c|c|c|c|c|}
\hline & \multicolumn{2}{|c|}{ Overall } & \multicolumn{2}{|c|}{ Men } & \multicolumn{2}{|c|}{ Women } \\
\hline & $N$ & Mean & $N$ & Mean & $N$ & Mean \\
\hline Age (18-89 years) & 987 & 43.85 & 494 & 43.44 & 493 & 44.25 \\
\hline Education $(0-20$ years $)$ & 1192 & 13.77 & 590 & 13.94 & 602 & 13.60 \\
\hline Generalized anxiety (scale $1-10$ ) & 1089 & 3.00 & 543 & 2.97 & 546 & 3.03 \\
\hline Financial anxiety (scale 1-10) & 1175 & 3.51 & 581 & 3.51 & 594 & 3.51 \\
\hline Crime prevention ( $0-8$ behaviours) & 1115 & $2.96^{*}$ & 558 & 2.04 & 557 & 3.89 \\
\hline Health promotion ( $0-7$ behaviours) & 1172 & $4.28 *$ & 577 & 4.01 & 595 & 4.55 \\
\hline Home protection $(0-5$ behaviours $)$ & 1160 & 3.53 & 574 & 3.54 & 586 & 3.52 \\
\hline \multirow[t]{2}{*}{$\begin{array}{l}\text { Like to be prepared/in control }[1-4 \\
\text { scale, } 1=\text { strongly agree }]\end{array}$} & 1193 & 1.82 & 592 & 1.82 & 601 & 1.82 \\
\hline & $N$ & $\%=1$ & $N$ & $\%=1$ & $N$ & $\%=1$ \\
\hline Sex (1=male) & 1200 & 49.45 & - & - & - & - \\
\hline Low income $(1<35,000)$ & 1058 & $22.21 *$ & 545 & 16.39 & 513 & 28.36 \\
\hline Middle income $(1=35,000-75,000)$ & 1058 & 49.61 & 545 & 51.74 & 513 & 47.35 \\
\hline Upper income $(1>75,000)$ & 1058 & $28.18 *$ & 545 & 31.87 & 513 & 24.29 \\
\hline Marital status (1=in partnership) & 1190 & 62.18 & 588 & 63.85 & 602 & 60.56 \\
\hline Crime victim (self) (1=yes) & 1200 & $34.47 *$ & 594 & 41.73 & 606 & 27.37 \\
\hline $\begin{array}{l}\text { Crime victim (close relation) } \\
\text { (1=yes) }\end{array}$ & 1182 & 27.54 & 583 & 29.05 & 599 & 26.07 \\
\hline Experienced illness (1=yes) & 1199 & 19.19 & 593 & 18.83 & 606 & 19.55 \\
\hline Experienced injury (1=yes) & 1199 & $16.94 *$ & 593 & 19.37 & 606 & 14.58 \\
\hline $\begin{array}{l}\text { Experienced natural disaster } \\
\text { (1=yes) }\end{array}$ & 1194 & $39.64 *$ & 590 & 44.98 & 604 & 34.44 \\
\hline $\begin{array}{l}\text { Experienced man-made disaster } \\
\text { (1=yes) }\end{array}$ & 1193 & $23.89 *$ & 590 & 31.47 & 603 & 16.48 \\
\hline Risk engagement ( $1=$ yes) & 1193 & $54.19 *$ & 589 & 62.92 & 604 & 45.68 \\
\hline
\end{tabular}


$15 \%$ have experienced a serious injury. Almost $40 \%$ have experienced a natural disaster, and nearly $24 \%$ have experienced a man-made disaster.

There are a number of gender differences in the descriptive results. Not surprisingly, women engage in almost twice as many crime prevention behaviours as do men, and they also engage in significantly more health promotion behaviours than men. On average, women in our sample have lower incomes than men; have been victims of personal crime less often than men; and fewer women than men have experienced a serious injury. Perhaps most strikingly, fewer women than men (as a percentage) have experienced natural or man-made disasters, particularly the latter. We speculate that this has something to do with many more men than women employed in industries in which one is likely to encounter these types of events. Alberta has a very active oil and gas industry, so it is perhaps unsurprising that almost twice as many men than women have experienced gas leaks, for example. Though these (and other) disaster events may occur at work, they become part of respondents' biographies. Experiences at work may influence one's sense of vulnerability, leading one to take measures where one can - at home.

\section{RESULTS}

After carefully examining the results of Table 1 above it becomes obvious that the differences between men and women are substantial. These findings further justify running separate regression models for men and women in order to fully appreciate how social contexts and the different aspects of biography influence the use of precautionary or protective behaviours in each of the three realms (crime, health, and home safety). We confirmed these differences by checking for sex interactions in a full model and found significant interaction effects in the crime and health models but not in the home safety models. However, split models are shown for all three realms in order to simplify presentation.

Before proceeding to the regression models, it is important to understand the interrelation between the realms under consideration. Are the protective behaviours taken in one realm related to the behaviours taken in another realm? For men, (see Table 2A), there is a small but significant positive relationship between all three realms suggesting that there is some relationship between taking precautions or protections between realms. However, relationships between realms are less clear for women (see Table 2B). There is no relationship between engaging in crime protection and engaging in either health promotion or home safety preparedness behaviours for women. There is only a weak positive 
Table 2: Correlations Among Realms By Gender

\begin{tabular}{l|c|c|c}
\multicolumn{1}{c|}{ 2A. MALES } & Crime Protection & Health Promotion & Home Protection \\
\hline Crime Protection & 1.00 & & \\
\hline Health Promotion & $.133^{* *}$ & 1.00 & \\
\hline Disaster Preparedness & $.151^{* *}$ & $.160^{* *}$ & 1.00
\end{tabular}

$* \mathrm{p}<0.05 * * \mathrm{p}<0.01$

\begin{tabular}{l|c|c|c}
\multicolumn{1}{c|}{ 2B. FEMALES } & Crime Protection & Health Promotion & Home Protection \\
\hline Crime Protection & 1.00 & & \\
\hline Health Promotion & .039 & 1.00 & \\
\hline Disaster Preparedness & .045 & $.106^{*}$ & 1.00
\end{tabular}

$* \mathrm{p}<0.05 * * \mathrm{p}<0.01$

relationship for women between health promotion and home safety preparedness behaviours.

We can more clearly see the differences and similarities between the realms for both men and women by examining the multivariate models for each of the three realms and identifying the similarities and differences between them. These models are presented in Table 3 .

\section{Social Context}

It is apparent from the results that factors relating to social context may influence protective behaviours, but only in certain realms. Social context appears not to influence crime protection behaviours for either men or women when controlling for the influence of biographical factors. However, there is evidence that social context (demographics) influences health promotion and home safety preparedness for both men and women. The exact nature of the influence varies both across realms and between the sexes.

For both the health promotion and the home safety models, we see that as age increases for men and women, there is greater engagement in protective behaviours. For the health promotion model, increased education also appears to influence individuals to engage in health promotion behaviours regardless of gender. There is a clear difference between the health promotion model and the home safety model with respect to education, however, and this difference is gendered. There is no effect of education regarding home safety for women and the effect for men is contrary to what might be expected: men with higher education engage in fewer home safety measures.

Turning to the effect of income, we find that income is a significant predictor only in the home safety preparedness model and this effect is largely the same for men and women. The higher an individual's income 
Table 3: Predicting Prevention (OLS Regression Coefficients)

\begin{tabular}{|c|c|c|c|c|c|c|}
\hline & \multicolumn{2}{|c|}{ Crime Protection } & \multicolumn{2}{|c|}{ Health Promotion } & \multicolumn{2}{|c|}{ Home Safety } \\
\hline \multicolumn{7}{|c|}{ Social Context } \\
\hline & $M$ & $F$ & $M$ & $F$ & $M$ & $F$ \\
\hline Age & $\begin{array}{l}-.007 \\
(.007)\end{array}$ & $\begin{array}{l}-.012 \\
(.008)\end{array}$ & $\begin{array}{l}.032 * * \\
(.006)\end{array}$ & $\begin{array}{l}.033 * * \\
(.006)\end{array}$ & $\begin{array}{l}.017 * * \\
(.004)\end{array}$ & $\begin{array}{l}.016^{* *} \\
(.004)\end{array}$ \\
\hline Education (yrs) & $\begin{array}{l}-.024 \\
(.040) \\
\end{array}$ & $\begin{array}{c}.028 \\
(.059) \\
\end{array}$ & $\begin{array}{l}.121 * * \\
(.037)\end{array}$ & $\begin{array}{l}.140 * * \\
(.038)\end{array}$ & $\begin{array}{l}-.056^{*} \\
(.028) \\
\end{array}$ & $\begin{array}{l}-.0005 \\
(.033) \\
\end{array}$ \\
\hline Middle income & $\begin{array}{l}-.174 \\
(.295) \\
\end{array}$ & $\begin{array}{l}-.182 \\
(.257) \\
\end{array}$ & $\begin{array}{l}-.340 \\
(.232) \\
\end{array}$ & $\begin{array}{l}-.262 \\
(.229) \\
\end{array}$ & $\begin{array}{l}.391^{*} \\
(.173) \\
\end{array}$ & $\begin{array}{l}.300 \\
(.161) \\
\end{array}$ \\
\hline Upper income & $\begin{array}{l}-.326 \\
(.321)\end{array}$ & $\begin{array}{l}-.072 \\
(.332)\end{array}$ & $\begin{array}{l}.160 \\
(.257)\end{array}$ & $\begin{array}{l}-.311 \\
(.270)\end{array}$ & $\begin{array}{l}.556^{* *} \\
(.190)\end{array}$ & $\begin{array}{l}.495 * * \\
(.189)\end{array}$ \\
\hline Marital status (Mar./CL=1) & $\begin{array}{l}-.223 \\
(.186) \\
\end{array}$ & $\begin{array}{l}-.391 \\
(.226) \\
\end{array}$ & $\begin{array}{l}-.111 \\
(.174) \\
\end{array}$ & $\begin{array}{l}.422^{*} \\
(.207) \\
\end{array}$ & $\begin{array}{l}.412^{* * *} \\
(.140) \\
\end{array}$ & $\begin{array}{l}.189 \\
(.137) \\
\end{array}$ \\
\hline \multicolumn{7}{|c|}{ Biography } \\
\hline \multicolumn{7}{|c|}{ Past Experience } \\
\hline Past crime victim (self) & $\begin{array}{c}.226 \\
(.176) \\
\end{array}$ & $\begin{array}{c}.162 \\
(.239) \\
\end{array}$ & \begin{tabular}{|l|}
-.087 \\
$(.175)$ \\
\end{tabular} & $\begin{array}{c}.260 \\
(.186) \\
\end{array}$ & $\begin{array}{l}-.286^{*} \\
(.122) \\
\end{array}$ & $\begin{array}{l}.322 * \\
(.134) \\
\end{array}$ \\
\hline $\begin{array}{l}\text { Past crime victim (close } \\
\text { relation) }\end{array}$ & $\begin{array}{l}-.097 \\
(.567)\end{array}$ & $\begin{array}{l}-.220 \\
(.257)\end{array}$ & $\begin{array}{c}.230 \\
(.185) \\
\end{array}$ & $\begin{array}{l}-.058 \\
(.203)\end{array}$ & $\begin{array}{l}-.009 \\
(.131)\end{array}$ & $\begin{array}{l}.342 * \\
(.133)\end{array}$ \\
\hline Past injury & $\begin{array}{l}-.105 \\
(.205)\end{array}$ & $\begin{array}{l}-.150 \\
(.289)\end{array}$ & $\begin{array}{c}-.570 * * \\
(.209)\end{array}$ & $\begin{array}{l}-.228 \\
(.258)\end{array}$ & $\begin{array}{l}.115 \\
(.150)\end{array}$ & $\begin{array}{l}.588 * * \\
(.149)\end{array}$ \\
\hline Past illness & $\begin{array}{c}.462 \\
(.248) \\
\end{array}$ & $\begin{array}{c}.367 \\
(.284) \\
\end{array}$ & $\begin{array}{l}.673 * * \\
(.232)\end{array}$ & $\begin{array}{l}.033 \\
(.212) \\
\end{array}$ & $\begin{array}{l}.299^{*} \\
(.144)\end{array}$ & $\begin{array}{l}-.113 \\
(.147)\end{array}$ \\
\hline Past natural disaster & $\begin{array}{l}.365^{*} \\
(.167)\end{array}$ & $\begin{array}{c}.214 \\
(.218)\end{array}$ & $\begin{array}{l}.364^{*} \\
(.165)\end{array}$ & $\begin{array}{l}-.041 \\
(.166)\end{array}$ & $\begin{array}{c}.151 \\
(.118)\end{array}$ & $\begin{array}{c}.105 \\
(.121)\end{array}$ \\
\hline Past man-made disaster & $\begin{array}{l}-.039 \\
(.191) \\
\end{array}$ & $\begin{array}{l}-.234 \\
(.302) \\
\end{array}$ & $\begin{array}{l}-.235 \\
(.184) \\
\end{array}$ & $\begin{array}{c}.149 \\
(.207) \\
\end{array}$ & $\begin{array}{l}-.072 \\
(.132) \\
\end{array}$ & $\begin{array}{l}-.253 \\
(.157) \\
\end{array}$ \\
\hline \multicolumn{7}{|c|}{ Anxiety } \\
\hline Generalized anxiety & $\begin{array}{l}.389 * * \\
(.085)\end{array}$ & $\begin{array}{l}.330^{* *} \\
(.090)\end{array}$ & $\begin{array}{c}.017 \\
(.080)\end{array}$ & $\begin{array}{c}.013 \\
(.065)\end{array}$ & $\begin{array}{l}.122^{*} \\
(.054)\end{array}$ & $\begin{array}{l}-.093 * \\
(.044)\end{array}$ \\
\hline Financial anxiety & $\begin{array}{c}-.107 * * \\
(.036)\end{array}$ & $\begin{array}{c}-.055 \\
(.050) \\
\end{array}$ & $\begin{array}{c}.020 \\
(.039) \\
\end{array}$ & $\begin{array}{l}-.078^{*} \\
(.038)\end{array}$ & $\begin{array}{c}.028 \\
(.024) \\
\end{array}$ & $\begin{array}{c}-.001 \\
(.025) \\
\end{array}$ \\
\hline \multicolumn{7}{|c|}{ Control } \\
\hline Preparedness/control & $\begin{array}{c}-.370 * * \\
(.129)\end{array}$ & $\begin{array}{l}-.176 \\
(.190)\end{array}$ & $\begin{array}{c}-.192 \\
(.127)\end{array}$ & $\begin{array}{l}.343 * \\
(.140)\end{array}$ & $\begin{array}{l}.206 * \\
(.093)\end{array}$ & $\begin{array}{c}-.080 \\
(.099)\end{array}$ \\
\hline Risk engagement & \begin{tabular}{|c}
$-.562^{* *}$ \\
$(.179)$ \\
\end{tabular} & $\begin{array}{l}-.236 \\
(.216) \\
\end{array}$ & $\begin{array}{c}.119 \\
(.170) \\
\end{array}$ & \begin{tabular}{|c|}
-.083 \\
$(.166)$ \\
\end{tabular} & $\begin{array}{c}.225 \\
(.122) \\
\end{array}$ & \begin{tabular}{|c}
.126 \\
$(.116)$ \\
\end{tabular} \\
\hline Constant & $\begin{array}{c}3.025^{* *} \\
(.728)\end{array}$ & $\begin{array}{l}4.012 * * \\
(1.131)\end{array}$ & $\begin{array}{l}1.190 \\
(.691)\end{array}$ & $\begin{array}{c}1.931 * * \\
(.698) \\
\end{array}$ & $\begin{array}{c}2.694 * * \\
(.523)\end{array}$ & $\begin{array}{c}2.567 * * * \\
(.591)\end{array}$ \\
\hline $\mathrm{R}^{2}$ & .1228 & .0856 & .1986 & .1523 & .1900 & .1427 \\
\hline
\end{tabular}

$* \mathrm{p}<0.05 * * \mathrm{p}<0.01$

the more likely he or she is to engage in home safety measures regardless of sex.

The influence of marital status is also gendered and differs between the health and the home safety realms. Women who are in a partnered relationship engage in more health promotion behaviours than women 
who are not. In addition, there is no effect of marital status for men once we control for biography. The opposite effect is seen in the home safety realm. In this realm, men who are in a partnered relationship are more likely to engage in home safety preparedness than those who are not. Marital status does not appear to influence whether or not women engage in home safety behaviours.

\section{BiograPhy}

The influence of biography on the likelihood of an individual to engage in health promotion, crime prevention, or home safety measures is clearly gendered and differs across realms.

\section{Past Experience}

One of the elements of biography that may influence engagement in precautionary behaviours, regardless of the realm, is past negative experience. The assumption is that past experiences may affect current actions. The influence of past experience is unexpected, gendered, and differs between the three realms. Past experience with crime is only influential in the home safety model. For men, it is being a crime victim oneself that reduces home safety preparedness activities. However, for women, we see the opposite effect, that having experienced a crime in one's past, either directly or indirectly, increases the engagement in home safety measures.

Past health experiences appear to influence both health promotion and home safety behaviours and are clearly gendered. Regarding health promotion activities, there appears to be no effect of past health experiences on engaging in health promotion activities for women. However, for men, the two types of prior experience (illness and injury) significantly influence the likelihood of engaging in health promotion behaviours but in opposite directions. Men who have experienced a significant injury in their past engage in fewer health promotion behaviours than those men who have not experienced a significant injury. However, experiencing a significant illness in the past appears to encourage men to increase the use of health promotion behaviours. Past health experiences also influence whether or not men and women engage in home safety preparedness activities. For women, the experience of a significant past injury increases the home safety preparedness activities engaged in. For men, it is the experience of a significant illness in the past that appears to increase home safety preparedness activities. 
The impacts of past experiences with disaster are moderated by gender. In addition, the influence of these experiences across the three realms is varied. Past experiences with disaster do not appear to influence the engagement of women in any of the three realms of precautionary behaviours. For men, past experience with a natural disaster increases the engagement in both crime protection and health promotion behaviours. There is no effect of previous disaster experiences on the use of home safety measures for men.

\section{Anxiety}

We expected anxiety to be influential in understanding how biography affects the use of precautionary behaviours across the three realms considered here, yet there is no effect of our anxiety measures on health promotion activities for either men or women. For women, greater levels of generalized anxiety concerning the future appear to increase the use of crime protection behaviours. Indeed, this is the only significant factor in the crime protection model for women. However, generalized anxiety has the opposite effect on home safety preparedness for women. Increasing levels of generalized anxiety result in women tending to decrease their use of home safety preparedness activities. For men, increased levels of generalized anxiety result in greater use of both crime protection and home safety preparedness behaviours. In addition, men with higher levels of financial anxiety tend to engage in fewer crime protection activities.

Clearly, past (experiential), current (risk/control activity), and future (anxiety) expressions of biography influence the use of precautionary behaviours across realms. However, these influences are complex, differ across the three realms, and are clearly gendered. Further evidence of these complexities is found in the explanatory power of the various models. In the realm of crime protection, we are able to explain only $12.3 \%$ of the variation for men, and only $8.5 \%$ of the variation for women. We fare somewhat better in the health promotion and home protection realms, where we explain roughly $19-20 \%$ of the variation for men, and $14-15 \%$ for women.

\section{Control}

It is not only past experiences which constitute biography but also perceptions of control and anxiety (perception of the likelihood of future events). In this study, these perceptions influence all three realms under consideration but, as was found when past experiences were examined, these effects are clearly gendered. For women, it appears that only one 
component influences their use of health promotion behaviours: as preparedness and control in their daily activities increases so too does women's engagement in health promotion activities.

For men, a greater desire for preparation or control in their day-today activities increases both crime protection and home safety preparedness activities. In addition, male respondents who indicated that they engaged in risky activities were less likely to undertake crime protection behaviours than men who indicated that they did not enjoy engaging in such activities.

\section{Discussion ANd Conclusions}

With regard to theories about late modernity and risk society, Taylor (1997:59) observes that "for all of their gestures towards connecting global change to local expressions, few of these formulations advance any specific suggestions as to how this connection might be made" (1997:59). Giddens (1994) and Beck (1992) suggest that global change produces generalized feelings of anxiety and insecurity, which may affect what individuals actually do. Our findings suggest that this relationship may not be straightforward, and that anxiety may contribute to certain types of precautionary behaviours and not to others. For example, while we find that generalized anxiety significantly predicts precautionary behaviour in the realm of crime, it is not a significant factor in predicting health promotion activities, nor does it contribute as expected to women's home safety efforts. Individual experiences with victimization, injury and illness, and natural disasters appear to play an equally compelling role in the use of precautionary behaviours.

What does this say about the generalized anxiety presumably characteristic of the risk society? It suggests that anxiety may be less general than expected; anxiety may, in fact, be specific, or at least more pronounced within particular realms. At the same time, while we do not see a compelling statistical impact of anxiety on the identified precautionary behaviours, Hunt's (1999) observation that anxiety may have to reach a certain level before it becomes a significant factor in predicting behaviour may be useful in interpreting our findings. It may be that the level of anxiety has reached a value high enough to prompt crime protection behaviour, but has not reached a level high enough to affect health prevention activity. The baseline for anxiety resulting in precautionary behaviour may be lower for crime than for the other behaviours examined here. Hunt's observations may also address whether precautionary behaviours across these three realms originate from different dimensions 
or sources of anxiety which may, in turn, contribute in various ways to behaviour. Similarly, it could be that local expression of anxiety consists of consciously choosing not to participate in particular forms of protective measures. It may also be that the regression models employed here are simply less effective at identifying the relationships we might expect to see.

Haggerty's (2003) observations may also come into play in interpreting our findings. As we mentioned above, our measure of generalized anxiety may not include all of the aspects of anxiety that may be relevant today. For example, our questions regarding anxiety speak to respondents' calculations about the likelihood of future events. Our measure of anxiety speaks less to dimensions of anxiety that may be emotionally or culturally based. Perhaps the somewhat weaker associations of generalized anxiety in the health and home safety realms is due to the fact that we may have captured only certain aspects of anxiety by asking whether respondents think it likely that they will have negative experiences in these realms in the future. Our measures may fail to capture, for example, an emotive dimension of anxiety - the degree to which respondents are worried about potential events, or their perceptions of whether they are encouraged to be worried through media reports, etc. We also note that several of our indicators of home safety preparedness speak more directly to events such as house fires than they do to larger scale events like tornados or nuclear radiation - measures that were included in the generalized anxiety scale. Further, fire extinguishers and smoke detectors may be geared more toward obtaining lower insurance rates than they are to preparation for home safety.

The significance of experience, a very local factor, in predicting precautionary behaviour cannot be overlooked. Our measurement of generalized anxiety focuses specifically on the future and respondents' predictions of particular future events. It may be that even these types of future events are too abstract to manifest themselves in any concrete way in the types of precautionary behaviours that we have considered here. Instead, experiences which are local, along with reflections about control that are also local, may simply have more to do with precautionary behaviours than does an abstract future. As Haggerty also points out, self-interest may be reflected in precautionary behaviours related to local (personal) experiences and far less so to abstract futures.

Our data provide considerable support for the suggestion that we need to take social context and individual biography into account in order to understand precautionary behaviours. Social context, as measured by variables such as age, education, income, and marital status, is important in understanding precautionary behaviour, although in in- 
consistent and sometimes unexpected ways across realms. Dimensions of biography, including past experiences, perceived control, and anxiety also varied between realms. Further, although almost every sociodemographic measure of social context was significant in the home safety preparedness model, past experiences with disaster itself had no bearing on the actions respondents undertook to prepare themselves for potential future disasters. (Unfortunately, our data do not allow for more specific exploration of the exact type of disasters respondents may have experienced.)

The results that we have obtained with respect to crime prevention are perhaps not surprising - the crime models are least successful in terms of variance explained. We are bombarded with news reports and media images of crime, as well as with information about how to protect ourselves from being victimized by crime. Crime provides us with an "other" against whom we can guard our person and our home. But this may be precisely the problem. Although there may be a tangible, embodied threat against which we are protecting ourselves, unlike the realms of health and home safety, crime threat may present itself as less predictable precisely because of the social or human element characterizing crime threats - an actual offender against whom we must defend ourselves and our homes - in contrast to threats in the other realms. Being the (possible) victim of crime brings in another "body" (the offender) over which we have little control. This observation relates to the possibility that there are differences associated with the blameworthiness of negative events: we have less control over the weather and natural elements than we think we do over people who are the sources of crime events. What we do to prevent negative outcomes in these realms may therefore differ on that basis. Our data support this suggestion, as our measures of control were also found to be significant predictors of crime prevention behaviour yet for men only.

Our findings also indicate that there is some degree of crossover between the realms examined here. First, for both men and women, past negative experiences in one realm were shown to affect protective behaviours in other realms (the impact of past experiences in the realm of crime protection, however, is least pronounced). This provides evidence for what might seem an intuitive notion - that those who suffer some form of loss or negative experience (vulnerability) in one realm are more likely to prepare for or, alternatively, ignore possible danger in other realms. Policymakers may do well to study the implications of vulnerability in terms of past experiences, and the meanings that vulnerability has for men and women, within each respective realm. Moreover, this conclusion points to some variables not considered 
here (or perhaps not adequately measured) as driving this differential orientation towards precautionary behaviour for men and women. Crime protection behaviours, for example, did not appear to be driven by past experiences in either of the other realms, and in the case of health promotion behaviours, only a past health experience seemed to be important, and even then only for men.

One striking finding is that we are able to explain more of the variation for men than for women in all three realms. This is particularly pronounced in the case of the crime protection model, where we explain approximately 1.4 times the variation for men as for women; and about 1.3 times the variation for men as for women in each of the health and home safety models. Recall that in the realms of crime and health, women engage in significantly more precautionary behaviours than do men. Further, in the realm of crime, the standard deviation for men, as a percentage of the mean, is far greater than is the case for women (results not presented). All of this together suggests that there are factors not measured in our models that are driving these precautionary behaviours, especially for women. Chan and Rigakos (2002) might suggest that because "men and women are required to confront and negotiate different types of risk in their lives" the measures of both prevention and anxiety that we employ in this study may simply not reveal that which impacts more significantly on women's experiences.

What these findings may in fact point toward is the possibility of different gender scripts (Fonow 1998) for women and men with respect to precautionary behaviours. If dominant models of masculinity and femininity in various institutions (gender regimes; see Connell 2002) and in society more broadly (Connell's gender order) construct women as risk managers and men as risk takers, it should come as no surprise that women engage in more precautionary behaviours, and that we seem less able to explain these behaviours for women with variables that capture either sociohistorical context or biography. Alternatively, our measure of generalized anxiety may not include dimensions that are of greater significance for women than for men. There may very well be different sets of sanctions and rewards for women and men around, for example, expressing emotional vulnerability to hazard. Our findings provide further evidence that risk and risk management are indeed gendered as other observers have suggested. It also, however, highlights that this seems to be much more the case with respect to crime than health, and perhaps less so with respect to home safety preparedness. Home safety may require more unpacking than we are able to do here. It would be useful, for example, to further investigate home safety preparedness with regard 
to divisions of labour found within households, and between men and women within their shared homes.

Several of the questions raised by our analysis also point to the importance of bringing longitudinal data to bear on these issues. This would allow us to examine various cohort effects that may prove important in shedding light on the nuances of the issues described above. It may be, for instance, that the relevance of past experiences to current precautionary behaviours is different for those in different birth cohorts. Similarly, if Beck and Giddens are correct in positing that the anxieties of today have only recently come about as the technologies that create global risks have become ubiquitous, longitudinal analysis may reveal important insights into how these anxieties might operate differently for different segments of the population. It may be that the rational dimension of anxiety is more salient for older cohorts while the emotive element is more germane for younger cohorts. The operation of gender regarding rational (masculine) versus emotive (feminine) scripts or risk management (feminine) versus risk-taking (masculine) would look very different, we contend, for birth cohorts who have no presecond-wave feminist history than for those who were born in an era where gendered divisions of labour were even more firmly entrenched than they are now.

Given that there have been so few studies that are able to simultaneously consider realms ostensibly as diverse as crime, health, and home safety, our findings contribute to understanding the interconnections between these realms of experience and their implications for men and women regarding the connections between local expressions of anxiety and global change. Bauman (2000) suggests that individuals may attempt to solve structured problems with biographical (individual) solutions. Our findings suggest that gender provides a lens through which biographical solutions may be delivered, but also a lens through which structured problems may be interpreted. Further, the role that individual experience plays in predicting biographical solutions is substantial: structured problems may be increasingly salient to the extent that they have been personally experienced, with local experiences also providing a lens through which biographical solutions to crime, ill-health, and safety are viewed. Our findings support the suggestion that the realm of crime must be rendered more social by examining the effect of social context on the discourses of crime (and crime protection) as well as the impact of personal biography for both men and women. Given that crime, ill-health, and home safety threats may be "knowable, decisionable (actionable) and potentially controllable" (Hollway and Jefferson 1997:265) and that this may serve to reduce or at least address generalized anxiety, our study of how these realms do or do not crossover pro- 
vides an initial step toward understanding how protective responses relate to the anxieties that ostensibly characterize this late modern moment.

\section{REFERENCES}

Bauman, Zygmunt. 2000. Liquid Modernity. Oxford: Polity.

Beck, Ulrich. 1992. Risk Society: Towards a New Modernity. Newbury Park, CA: Sage.

2003. The silence of words: On terror and war. Security Dialogue 34(3):255-267.

Bord, Richard J. and Robert E. O'Connor. 1997. The gender gap in environmental attitudes: The case of perceived vulnerability to risk. Social Science Quarterly 78(4):830-840.

Chan, Wendy and George Rigakos. 2002. Risk, crime and gender. British Journal of Criminology 42(4):743-761.

Connell, Robert W. 2002. Gender. Cambridge: Polity Press.

Culley, Marci R., and Holly L. Angelique. 2003. Women's gendered experiences as long-term Three Mile Island activists. Gender \& Society 17(3):445461.

Douglas, Mary. 1992. Risk and Blame: Essays in Cultural Theory. London: Routledge.

Farrall, Stephen, Jon Bannister, Jason Ditton, and Elizabeth Gilchrist. 1997. Questioning the measurement of the 'fear of crime': Findings from a major methodological study. British Journal of Criminology 37(4):658-79.

Fonow, Mary M. 1998. Protest engendered: The participation of women steelworkers in the Wheeling-Pittsburgh steel strike of 1985. Gender \& Society 12(6):710-728.

Fothergill, Alice. 1996. Gender, risk and disaster. International Journal of Mass Emergencies and Disasters 14(1):33-56.

Frosh, Stephen and Peter D. Emerson. 2005. Interpretation and over-interpretation: Disputing the meaning of texts. Qualitative Research 3:307-324.

Garland, David. 1996. The limits of the sovereign state: Strategies of crime control in contemporary society. British Journal of Criminology 36(4):445-471.

Giddens, Anthony. 1994. Living in a post-traditional society. Pp. 56-109 in U. Beck, A. Giddens and S. Lash, eds., Reflexive Modernization: Politics, Tradition and Aesthetics in the Modern Social Order. Cambridge, MA: Polity Press.

Grey, Emily, Jonathan Jackson, and Stephen Farrall. 2008. Reassessing the fear of crime. European Journal of Criminology 5(3):363-380. 
Haggerty, Kevin. 2003. From risk to precaution: The rationalities of crime prevention. Pp. 193-214 in R. Ericson and A. Doyle, eds., Risk and Morality. Toronto: University of Toronto Press.

Hollander, Jocelyn A. 2001. Vulnerability and dangerousness: The construction of danger through conversations about violence. Gender and Society 15(1):83-109.

Hollway, Wendy and Tony Jefferson. 1997. The risk society in an age of anxiety: Situating fear of crime. British Journal of Sociology 48(2):255-266. 2000. Doing Qualitative Research Differently. London: Routledge.

Hunt, Alan. 1999. Anxiety and social explanation: Some anxieties about anxiety. Journal of Social History 32(3):509-528.

Kay, Joanne and Suzanne Laberge. 2004. 'Mandatory equipment': Women in adventure racing. Pp. 154-174 in B. Wheaton, ed., Understanding Lifestyle Sport: Consumption, Identity and Difference. London: Routledge.

Krewski, Daniel, Louise Lemyre, Michelle C. Turner, Jennifer E.C. Lee, Christine Dallaire, Louise Bouchard, Kevin Brand, and Pierre Mercier. 2008. Public perception of population health risks in Canada: Risk perception beliefs. Health, Risk and Society 10(2):167-179.

Madriz, Esther. 1997. Images of criminals and victims: A study on women's fear and social control. Gender \& Society 11(3):342-356.

McCaughey, Martha. 1997. Reel Knockouts: The Physical Feminism of Women's Self-defense. New York: New York University Press.

Mythen, Gabe and Sandra Walklate. 2006. Criminology and terrorism: Which thesis? Risk society or governmentality? British Journal of Criminology 46:379-398.

Norris, Fran. H., Tenbroeck Smith, and Krzysztof Kaniasty. 1999. Revisiting the experience-behavior hypothesis: The effects of Hurricane Hugo on hazard preparedness and other self-protective acts. Basic and Applied Social Psychology 21(1):37-47.

Risor, Mette Bech. 2006. Illness behavior and functional somatic symptoms - Rethinking the concept of illness behavior from an anthropological perspective. Social Theory and Health 4(2):180-201.

Smith, Richard D. 2006. Responding to global infectious disease outbreaks: Lessons from SARS on the role of risk perception, communication and management. Social Science and Medicine 68(12):3113-3123.

Taylor, Ian. 1997. Crime, anxiety and locality: Responding to the 'condition of England' at the end of the century. Theoretical Criminology 1(1):53-75.

Tulloch, Marian I. 2004. Parental fear of crime: A discursive analysis. Journal of Sociology 40(4):362-377.

Walklate, Sandra. 1997. Risk and criminal victimization: A modernist dilemma? British Journal of Criminology 37(1):35-45. 


\section{Appendix One: Measurement Summary}

\begin{tabular}{|c|c|}
\hline Variable & Defined as \\
\hline Sex & $1=$ male, $0=$ female \\
\hline Age & Years \\
\hline Income & $\begin{array}{l}\text { Divided into three groups } \\
\text { Low Income }<25,000 \\
\text { Middle Income } 35,000-75,000 \\
\text { Upper Income }>75,000\end{array}$ \\
\hline $\begin{array}{l}\text { Education } \\
\text { level }\end{array}$ & $\begin{array}{l}\text { Years (recoded from response categories indicating level of educational } \\
\text { attainment) }\end{array}$ \\
\hline $\begin{array}{l}\text { Marital } \\
\text { Status }\end{array}$ & $\begin{array}{l}1=\text { in partnership (married or common-law) } \\
0=\text { single, widowed, divorced, separated }\end{array}$ \\
\hline $\begin{array}{l}\text { Generalized } \\
\text { Anxiety }\end{array}$ & $\begin{array}{l}\text { The questions were framed as follows: "Please rate the chance that a } \\
\text { specific event will happen to you in the next five years. On a scale of } 1 \text { to } \\
10, \text { where } 1 \text { means it's 'not at all likely' and } 10 \text { means it's 'very likely' - } \\
\text { how likely do you think it is that..." } \\
\text { Someone will break into your home while you are away? } \\
\text { You will be physically attacked? } \\
\text { Your property will be stolen? } \\
\text { A member of your family will be assaulted? } \\
\text { You will contract a life threatening illness? } \\
\text { You will be affected by a major biological health threat? } \\
\text { You will have a heart attack? } \\
\text { You will be exposed to HIV or contract AIDS? } \\
\text { You will be adversely affected by genetically altered foods? } \\
\text { You will experience a fire? } \\
\text { You will be exposed to nuclear radiation? } \\
\text { You will be exposed to a chemical hazard? } \\
\text { You will become ill due to polluted drinking water? } \\
\text { You will experience a tornado? } \\
\text { (Final Measure summed and divided to retain original 1-10 scaling.) (see } \\
\text { text for details) }\end{array}$ \\
\hline $\begin{array}{l}\text { Financial } \\
\text { Anxiety }\end{array}$ & $\begin{array}{l}\text { On a scale of } 1 \text { to } 10 \text {, where } 1 \text { means it's 'not at all likely' and } 10 \text { means } \\
\text { it's 'very likely' - how likely do you think it is that you will face a major } \\
\text { financial hardship? }\end{array}$ \\
\hline $\begin{array}{l}\text { Crime } \\
\text { Protection }\end{array}$ & $\begin{array}{l}\text { [Code: } 1=\text { yes, } 0=\text { no] } \\
\text { Do you routinely... } \\
\text { Carry something (weapon, pepper spray) to defend yourself or (whistle) to } \\
\text { alert other people? } \\
\text { Lock the car doors when alone in a car? } \\
\text { Check the back seat for intruders when returning alone to a parked car? } \\
\text { Stay at home at night because you are afraid to go out alone? } \\
\text { Avoid certain areas because of crime? } \\
\text { Keep lights on when home alone? } \\
\text { Close your blinds or curtains when home alone? } \\
\text { Hold your keys defensively when walking alone at night? }\end{array}$ \\
\hline
\end{tabular}




\begin{tabular}{|c|c|}
\hline $\begin{array}{l}\text { Health } \\
\text { Promotion }\end{array}$ & $\begin{array}{l}\text { [Coded as: } 1=\text { 'always' or 'often', } 0=\text { 'seldom' or 'never'.] } \\
\text { Do you avoid fat in your diet? } \\
\text { Do you avoid cholesterol in your diet? } \\
\text { Do you avoid salt in your diet? } \\
\text { Do you avoid loud noise? } \\
\text { Do you eat fruits and vegetables? } \\
\text { Do you take vitamins? } \\
\text { Do you regularly smoke? [R-coded] }\end{array}$ \\
\hline $\begin{array}{l}\text { Home } \\
\text { Safety } \\
\text { Prepared- } \\
\text { ness }\end{array}$ & $\begin{array}{l}\text { [Code: } 1=\text { yes, } 0=\text { no] } \\
\text { Do you own a working battery-powered radio at home? } \\
\text { Do you have working smoke alarms/detectors at home? } \\
\text { Do you have a first aid kit at home? } \\
\text { Do you have a working fire extinguisher at home? } \\
\text { Do you have a plan to follow in case of a house fire? }\end{array}$ \\
\hline $\begin{array}{l}\text { Crime } \\
\text { Experience }\end{array}$ & $\begin{array}{l}\text { [Code: } 1=\text { yes, } 0=\text { no] } \\
\text { An attack can be anything from being hit, slapped, pushed or grabbed, to } \\
\text { being shot or beaten. Have you ever been attacked by anyone? Has this } \\
\text { been in the last } 12 \text { months? } \\
\text { Has a close friend or relative of yours been the victim of a crime in the last } \\
12 \text { months? }\end{array}$ \\
\hline $\begin{array}{l}\text { Ill-Health } \\
\text { Experience }\end{array}$ & $\begin{array}{l}{[\text { Code: } 1=\text { yes, } 0=\text { no] }} \\
\text { Have you had a major illness requiring hospitalisation in the past five } \\
\text { years? } \\
\text { Have you had a major injury in the past five years? }\end{array}$ \\
\hline $\begin{array}{l}\text { Disaster } \\
\text { Experience }\end{array}$ & $\begin{array}{l}\text { [Code: } 1=\text { yes, } 0=\text { no] } \\
\text { Have you directly experienced a major natural disaster (flood, forest fire, } \\
\text { and tornado) or its immediate effects? } \\
\text { Have you directly experienced a man-made disaster (gas leak or house } \\
\text { fire) or its immediate effects? }\end{array}$ \\
\hline $\begin{array}{l}\text { Risk } \\
\text { Engage- } \\
\text { ment }\end{array}$ & $\begin{array}{l}\text { Respondents asked level of agreement (strongly agree, agree somewhat, } \\
\text { disagree somewhat, strongly disagree) with the following statement: } \\
\text { I like to test myself every now and then by doing something risky. } \\
\text { (Recoded to agree }=1 \text { disagree }=0 \text { ) }\end{array}$ \\
\hline $\begin{array}{l}\text { Prepare/ } \\
\text { Control }\end{array}$ & $\begin{array}{l}\text { Respondents asked level of agreement (strongly agree, agree somewhat, } \\
\text { disagree somewhat, strongly disagree) with the following statements: } \\
\text { I devote much thought and effort to preparing for the future. } \\
\text { When things get complicated, I tend to try even harder. } \\
\text { (Responses summed and divided by } 2 \text { ) }\end{array}$ \\
\hline
\end{tabular}

Erin Gibbs Van Brunschot is Associate Professor in the department of Sociology at the University of Calgary and Associate Dean for the Faculty of Social Sciences. In 2008, she authored Risk Balance and Security (Sage) with Les Kennedy, which reflects her ongoing interests in the realms of risk, security and crime. She is presently co-authoring a book entitled, Risk in Crime with Les Kennedy.

Jason Laurendeau is Assistant Professor in the Sociology Department at the University of Lethbridge. His research interests include voluntary risk activities, deviance and social control, and gender. His current research project is an ethnographic interrogation of the intersection of risk and gender in B.A.S.E. jumping.

Leslie-Anne Keown is an Adjunct Assistant Professor at the University of Calgary in the Sociology Department. She works full-time as a Social Science 
Researcher for Statistics Canada in Ottawa doing research for Canadian Social Trends. Her research interests include incivility, personal crime precautions, victimization, and social engagement. Her current research focus is on diversity and deployment of social networks. 